\title{
Effects of drying and storage conditions in the quality of sunflower seeds
}

\author{
Efeitos das condições de secagem e armazenamento na \\ qualidade de sementes de girassol
}

Paulo Carteri Coradi ${ }^{*}$, Carlos Henrique Portela Fernandes ${ }^{1}$, Clayton Cerqueira Peralta ${ }^{1}$, Taísa Lacerda Pereira ${ }^{1}$

'Universidade Federal de Mato Grosso do Sul, Campus Chapadão do Sul, Rodovia MS 306, Km 105 Caixa Postal 112, CEP 79560-000 Chapadão do Sul, MS, Brazil

*autor correspondente

\. paulo.coradi@ufms.br

\begin{abstract}
The viability of seeds passing through the appropriate conditions of harvest and post -harvest storage and the step. The objective of this study was to evaluate the physiological potential of sunflower seeds under different storage conditions $\left(25{ }^{\circ} \mathrm{C}\right.$ and $50 \%, 20{ }^{\circ} \mathrm{C}$ and $60 \%$, $30{ }^{\circ} \mathrm{C}$ and $40 \% \mathrm{RH}$ air) using different packages (permeable and impermeable). Physiological assessments were carried seeds in zero, three and six months of storage times and analyzed by the average test were compared by Tukey test at $5 \%$ probability. Under the conditions of $20{ }^{\circ} \mathrm{C}$ and $60 \% \mathrm{RH}$, and $25^{\circ} \mathrm{C}$ and $50 \% \mathrm{RH}$ in air and impermeable packaging obtained the best quality results. The physiological potential of sunflower seeds was affected by drying temperatures and storage conditions. The drying air temperature above $45{ }^{\circ} \mathrm{C}$ negatively affected the quality of sunflower seeds. Permeable and waterproof packaging not guaranteed the quality of sunflower seeds during storage. The quality of sunflower seeds stored up time of three months was negatively affected. The conditions of $20{ }^{\circ} \mathrm{C}$ and $60 \% \mathrm{RH}$ air were more favorable for the preservation of physiological quality of sunflower seed during the storage time.
\end{abstract}

KEYWORDS: Conservation, Helianthus annus L., quality.
RESUMO: A viabilidade das sementes passa pelas condições adequadas de colheita e pós-colheita, como a etapa de armazenamento. O objetivo deste trabalho foi avaliar o potencial fisiológico das sementes de girassol sob diferentes condições de armazenamento $\left(25^{\circ} \mathrm{Ce} 50 \%, 20^{\circ} \mathrm{Ce} 60 \%, 30^{\circ} \mathrm{Ce}\right.$ $40 \%$ de UR do ar) utilizando diferentes embalagens (permeáveis e impermeáveis). As avaliações fisiológicas das sementes foram realizadas nos tempos zero, três e seis meses de armazenamento e analisadas pelo teste de média, comparadas pelo teste Tukey a 5\% de probabilidade. Nas condições de $20{ }^{\circ} \mathrm{Ce} 60 \%$ UR e de $25^{\circ} \mathrm{Ce} 50 \%$ de UR do ar, para as embalagens impermeáveis obtiveram-se os melhores resultados de qualidade. O potencial fisiológico das sementes de girassol foi afetado pela temperatura do ar de secagem e condições de armazenamento. A temperatura do ar de secagem acima de $45^{\circ} \mathrm{C}$ afetou negativamente a qualidade das sementes de girassol. As embalagens permeáveis e impermeáveis não garantiram a qualidade das sementes de girassol ao longo do armazenamento. A qualidade das sementes de girassol armazenadas acima do tempo de três meses foi afetada negativamente. As condições de $20{ }^{\circ} \mathrm{C}$ e $60 \%$ de UR do ar foram as mais favoráveis para a conservação da qualidade fisiológico das sementes de girassol, ao longo do tempo de armazenamento.

PALAVRAS-CHAVE: Conservação, Helianthus annus L., qualidade. 


\section{Introduction}

Sunflower (Helianthus annus L.), a plant of the family Asteraceae, is native to North America, and until the seventeenth century, was grown as an ornamental and medicinal plant. In the eighteenth century was selected, in Russia, as oil producing plant, but only gained economic importance after World War II. Currently, constitutes the world's second largest source of edible vegetable oil. The sunflower can be an alternative in providing raw material for the extraction of oil, even in times where the oil extraction industry is idle. There is also the possibility of using its oil as fuel (BENNETT, 2011). Thus, most of the seeds after harvest have inadequate characteristics to be stored, mainly due to the high water content needing to be dry for storage (BAILEY, 1992; MARTINS; LAGO; ANDRADE, 2009).

The recommended water content for safe storage constitutes a very important factor and depends on the species, the environmental conditions of the region, the period and the type of packaging used. Some physical factors (temperature, moisture and mechanical damage) and biological (insects, mites and microorganisms) affect the preservation of stored grains. The water content much influence on the quality of stored produce, and seeds with high water content are an ideal medium for the growth of microorganisms, insects and mites (PRADHAN et al., 2009) medium. The storage can reduce the seed longevity mainly by the effects of the external factors such as temperature and relative humidity of the ambient air, altering the water content and the speed of biochemical processes of seed. However, when seeds are stored at low temperatures the possibility of deterioration is smaller.

The most obvious physiological alterations of seeds by the effects of drying and storage are observed during germination and early seedling development. The disintegration of the membrane system of the seeds during storage has been a factor observed as for quality, altering the chemical instability of lipids provoking decrease in performance of the seeds (FESSEL et al., 2011; SANTOS et al., 2012).

Thus, it is useful for trials that evaluate germination, speed of emergence and seedling development during storage of seeds, so these have the potential to germinate or else have acceptable performance for the industry. The objective of this study was to evaluate the physiological potential of sunflower seeds under different storage conditions $\left(25^{\circ} \mathrm{C}\right.$ and $50 \%, 20^{\circ} \mathrm{C}$ and $60 \%, 30{ }^{\circ} \mathrm{C}$ and $40 \% \mathrm{RH}$ air), using different packaging (permeable and impermeable) for six months.

\section{Material and Methods}

The experimental work was developed at the Federal University of Mato Grosso do Sul (UFMS), Campus of Chapadão do Sul (CPCS), located in the municipality of Chapadão do Sul, MS, Brazil. The sunflower seeds were harvested at random, and possession of specimens' manual separation of impurities was taken damaged seeds. Then, the seeds were dried in a convection oven with forced air ventilation at temperatures of $45,55,65$ and $75^{\circ} \mathrm{C}$. Drying was carried out until the seeds reach the water content of $10.5 \%$ (w.b.), recommended for storage. For each temperature of the drying air drying, three tests were performed and for each test, $5 \mathrm{~kg}$ of sunflower seeds were used. The temperature and relative humidity were studio monitors, throughout drying with the aid of a psychrometer.

After drying, the seeds were stored in three different environments, namely, the natural environment $\left(25^{\circ} \mathrm{C}\right.$ and $\left.50 \%\right)$ and two climate chambers BOD $\left(20^{\circ} \mathrm{C}\right.$ and $60 \%, 30^{\circ} \mathrm{C}$ and $40 \% \mathrm{RH}$ air), two types of packing (windproof and waterproof) for a period of six months. Over time, the seeds stored along with the ambient temperature and relative humidity, with the aid of a psychrometer was monitored. To assess the quality of sunflower seeds after drying and during storage germination tests, accelerated aging, speed of emergence and seedling growth were performed.

The germination test was conducted with four replicates of 30 seeds of each treatment, in rolls of paper towel type "Germitest" in germinator type "Mangesdorf" set to maintain a constant temperature of $25 \pm 2{ }^{\circ} \mathrm{C}$. The amount of water added was equivalent to 2.5 times the mass of dry substrate, aiming at the adequate wetting and, consequently, the standardization of the test. The interpretations were made from the 4th day after sowing until the 10th day according to the criteria set out in the Rules for Seed Analysis (BRASIL, 2009).

The accelerated aging test was conducted using the method of seedling in plastic box type chamber of BOD, which were placed four grams of seeds on a screen attached to aluminum gerbox box, containing, at bottom, $40 \mathrm{ml}$ distilled water, and subsequently brought to the aging chamber (BOD) adjusted to $41^{\circ} \mathrm{C}$, lasting for periods of 48,72 and 96 hours. Then the seeds were subjected to germination test and evaluated on the sixth day after installation and the results expressed as percentage of normal seedlings (BRASIL, 2009).

The rate of emergence rate was determined from the sowing of sunflower seeds in trays of substrate, four replicates of 50 seeds for each sample. The emerged seedlings were counted daily between early (days 5) the emergence and stabilization of moment numerical scores (10th day after installation). The results were expressed as index of germination speed as Maguire (1962).

The seedling root length and sunflower seeds were evaluated in five samples of 20 seeds from each treatment were distributed in rolls of paper towels moistened with distilled water in the ratio of 2.5 per $1(\mathrm{ml}$ of distilled water for paper mass dry grams) and kept in a germination chamber at $25{ }^{\circ} \mathrm{C}$ for five days (NAKAGAWA, 1999). About the paper towel dampened a line was drawn in the upper third, in the longitudinal direction, where the seeds were placed micropyle is directing it down. The primary root length and seedling considered normal (BRASIL, 2009) was determined at the end of the fifth day, with the aid of a millimeter ruler.

The experimental design was completely randomized $(3 \times 3 \times 2)$, three temperatures of the drying air, three storage and two types of packages, with three replicates per treatment. Analysis of variance and means were compared by Tukey test at $5 \%$ probability were made. 


\section{Results and Discussion}

Physiological are related to the ability of the seed to perform their vital functions, characterized by vigor, germination and longevity. The reduction in quality is generally translated by a decrease in the percentage of germination; abnormal seedlings increased and reduced seedling vigor (TOLEDO et al., 2009). In Tables 1,2 and 3 are the results of germination of sunflower seeds. It was observed that the drying temperature above $45^{\circ} \mathrm{C}$ affect negatively the germination of seeds. While the effects of storage conditions were apparent over time, for seeds that have been dried at temperatures of 55,65 and $75^{\circ} \mathrm{C}$.

The first three months it was found that the storage conditions of $25{ }^{\circ} \mathrm{C}$ and $50 \% \mathrm{RH}$ in air provided a higher percentage of germinated seeds. However, after the third month of storage

Table 1. Sunflower seed germination (\%) according to the drying air temperature and storage conditions for each type of packaging and storage time.

\begin{tabular}{|c|c|c|c|c|c|c|}
\hline \multirow{2}{*}{$\begin{array}{l}\text { Storage time } \\
\text { (months) }\end{array}$} & \multirow{2}{*}{ Packing } & \multirow{2}{*}{$\begin{array}{c}\text { Storage } \\
\text { conditions }\end{array}$} & \multicolumn{4}{|c|}{ Temperature of the drying air } \\
\hline & & & $45^{\circ} \mathrm{C}$ & $55^{\circ} \mathrm{C}$ & $65^{\circ} \mathrm{C}$ & $75^{\circ} \mathrm{C}$ \\
\hline $\mathbf{0}$ & - & - & $100 \mathrm{a}$ & $94 \mathrm{~b}$ & $78 \mathrm{~d}$ & $84 \mathrm{c}$ \\
\hline \multirow{6}{*}{3} & \multirow{3}{*}{ Impermeable } & $20{ }^{\circ} \mathrm{C} / 60 \%$ & $96 \mathrm{Aa}$ & $82 \mathrm{Bb}$ & $82 \mathrm{Cb}$ & $86 \mathrm{Bb}$ \\
\hline & & $25^{\circ} \mathrm{C} / 50 \%$ & $94 \mathrm{Ab}$ & $100 \mathrm{Aa}$ & $88 \mathrm{Bc}$ & $10 \mathrm{Ca}$ \\
\hline & & $30{ }^{\circ} \mathrm{C} / 40 \%$ & $96 \mathrm{Ab}$ & $100 \mathrm{Aa}$ & $96 \mathrm{Ab}$ & $92 \mathrm{Ac}$ \\
\hline & \multirow{3}{*}{ Permeable } & $20{ }^{\circ} \mathrm{C} / 60 \%$ & $94 \mathrm{Ab}$ & $100 \mathrm{Aa}$ & $96 \mathrm{Ab}$ & $96 \mathrm{Ab}$ \\
\hline & & $25^{\circ} \mathrm{C} / 50 \%$ & 96 Aa & $96 \mathrm{Ba}$ & 96 Aa & 96 Aa \\
\hline & & $30{ }^{\circ} \mathrm{C} / 40 \%$ & $\mathbf{0} \mathbf{B a}$ & $\mathbf{0}$ Ca & O Ba & $\mathbf{0} \mathbf{B a}$ \\
\hline \multirow{6}{*}{6} & \multirow{3}{*}{ Impermeable } & $20{ }^{\circ} \mathrm{C} / 60 \%$ & $19 \mathrm{Bc}$ & $20 \mathrm{Ac}$ & 41 Aa & $31 \mathrm{Bc}$ \\
\hline & & $25^{\circ} \mathrm{C} / 50 \%$ & $22 \mathrm{Ab}$ & $17 \mathrm{Bc}$ & $30 \mathrm{Ca}$ & $28 \mathrm{Ca}$ \\
\hline & & $30{ }^{\circ} \mathrm{C} / 40 \%$ & $14 \mathrm{Cc}$ & $\mathbf{0}$ Cd & $37 \mathbf{B b}$ & $45 \mathrm{Aa}$ \\
\hline & \multirow{3}{*}{ Permeable } & $20{ }^{\circ} \mathrm{C} / 60 \%$ & $12 \mathrm{Bb}$ & $8 \mathrm{Bc}$ & $19 \mathrm{Ba}$ & $21 \mathrm{Aa}$ \\
\hline & & $25^{\circ} \mathrm{C} / \mathbf{5 0} \%$ & 32 Aa & 32 Aa & $26 \mathrm{Ab}$ & $0 \mathrm{Ba}$ \\
\hline & & $30{ }^{\circ} \mathrm{C} / 40 \%$ & $0 \mathrm{Ca}$ & $0 \mathrm{Ca}$ & $0 \mathrm{Ca}$ & 0 Ba \\
\hline
\end{tabular}

Means followed by the capital letter in the column for each storage condition and lower lines for each temperature of the drying air, do not differ at $5 \%$ probability. Coefficient of variation $(\mathrm{CV})=5.23 \%$.

Table 2. Sunflower seed germination (\%) according to the drying air temperature and time of storage for each type of packaging and storage conditions.

\begin{tabular}{|c|c|c|c|c|c|c|}
\hline \multirow{2}{*}{$\begin{array}{l}\text { Storage time } \\
\text { (months) }\end{array}$} & \multirow{2}{*}{ Packing } & \multirow{2}{*}{$\begin{array}{l}\text { Storage } \\
\text { conditions }\end{array}$} & \multicolumn{4}{|c|}{ Temperature of the drying air } \\
\hline & & & $45^{\circ} \mathrm{C}$ & $55^{\circ} \mathrm{C}$ & $65^{\circ} \mathrm{C}$ & $75^{\circ} \mathrm{C}$ \\
\hline $\mathbf{0}$ & & - & $100 \mathrm{Aa}$ & $94 \mathrm{Ab}$ & $78 \mathrm{Bd}$ & $84 \mathrm{Ac}$ \\
\hline 3 & Impermeable & $20{ }^{\circ} \mathrm{C} / 60 \%$ & $96 \mathrm{Ba}$ & $82 \mathrm{Bc}$ & $82 \mathrm{Ac}$ & $86 \mathrm{Ab}$ \\
\hline 6 & & $20{ }^{\circ} \mathrm{C} / 60 \%$ & $19 \mathrm{Cc}$ & $20 \mathrm{Cc}$ & $41 \mathrm{Ca}$ & $31 \mathrm{Bb}$ \\
\hline $\mathbf{0}$ & & - & $100 \mathrm{Aa}$ & $94 \mathrm{Bb}$ & $78 \mathrm{Bd}$ & $84 \mathrm{Bc}$ \\
\hline 3 & Permeable & $20{ }^{\circ} \mathrm{C} / 60 \%$ & $94 \mathrm{Bb}$ & $100 \mathrm{Aa}$ & $96 \mathrm{Ab}$ & $96 \mathrm{Ab}$ \\
\hline 6 & & $20{ }^{\circ} \mathrm{C} / 60 \%$ & $12 \mathrm{Cb}$ & $8 \mathrm{Cc}$ & $19 \mathrm{Ca}$ & $21 \mathrm{Ca}$ \\
\hline $\mathbf{0}$ & & - & $100 \mathrm{Aa}$ & $94 \mathrm{Bb}$ & $78 \mathrm{Bd}$ & $84 \mathrm{Bc}$ \\
\hline 3 & Impermeable & $25^{\circ} \mathrm{C} / \mathbf{5 0 \%}$ & $94 \mathrm{Bb}$ & $100 \mathrm{Aa}$ & $88 \mathrm{Ac}$ & $100 \mathrm{Aa}$ \\
\hline 6 & & $25^{\circ} \mathrm{C} / \mathbf{5 0} \%$ & $22 \mathrm{Cc}$ & $17 \mathrm{Cd}$ & $30 \mathrm{Ca}$ & $28 \mathrm{Cb}$ \\
\hline $\mathbf{0}$ & & - & $100 \mathrm{Aa}$ & $94 \mathrm{Ab}$ & 78 Bd & $84 \mathrm{Bc}$ \\
\hline 3 & Permeable & $25^{\circ} \mathrm{C} / \mathbf{5 0} \%$ & $96 \mathrm{Ba}$ & 96 Aa & $96 \mathrm{Aa}$ & $96 \mathrm{Aa}$ \\
\hline 6 & & $25^{\circ} \mathrm{C} / \mathbf{5 0} \%$ & $32 \mathrm{Ca}$ & $32 \mathbf{B a}$ & $26 \mathrm{Cb}$ & $0 \mathrm{Cc}$ \\
\hline $\mathbf{0}$ & & - & $100 \mathrm{Aa}$ & $94 \mathrm{Bb}$ & $78 \mathrm{Bd}$ & $84 \mathrm{Bc}$ \\
\hline 3 & Impermeable & $30{ }^{\circ} \mathrm{C} / 40 \%$ & $96 \mathrm{Bb}$ & $100 \mathrm{Aa}$ & $96 \mathrm{Ab}$ & $92 \mathrm{Ac}$ \\
\hline 6 & & $30{ }^{\circ} \mathrm{C} / 40 \%$ & $14 \mathrm{Cc}$ & 0 Cd & $37 \mathbf{C b}$ & $45 \mathrm{Ca}$ \\
\hline $\mathbf{0}$ & & - & $100 \mathrm{Aa}$ & $94 \mathrm{Ab}$ & $78 \mathrm{Ad}$ & $84 \mathrm{Ac}$ \\
\hline 3 & Permeable & $30{ }^{\circ} \mathrm{C} / 40 \%$ & O Ba & $0 \mathbf{B a}$ & $\mathbf{0} \mathbf{B a}$ & $0 \mathrm{Ba}$ \\
\hline 6 & & $30{ }^{\circ} \mathrm{C} / 40 \%$ & O Ba & $0 \mathrm{Ba}$ & $0 \mathrm{Ba}$ & 0 Ba \\
\hline
\end{tabular}

Means followed by the capital letter in the column for each storage time and lower lines for each temperature of the drying air, do not differ at $5 \%$ probability. Coefficient of variation $(\mathrm{CV})=4.41 \%$. 
Table 3. Sunflower seed germination (\%) versus time of storage and the type of packaging for each of the drying air temperature and storage condition.

\begin{tabular}{|c|c|c|c|c|c|}
\hline \multirow{2}{*}{$\begin{array}{l}\text { Drying air } \\
\text { temperature }\end{array}$} & \multirow{2}{*}{$\begin{array}{c}\text { Storage } \\
\text { conditions }\end{array}$} & \multirow{2}{*}{ Packing } & \multicolumn{3}{|c|}{ Time of storage (months) } \\
\hline & & & $\mathbf{0}$ & 3 & 6 \\
\hline \multirow{6}{*}{$45^{\circ} \mathrm{C}$} & \multirow{2}{*}{$20{ }^{\circ} \mathrm{C} / 60 \%$} & Impermeable & $100 \mathrm{Aa}$ & $96 \mathrm{Ab}$ & $19 \mathrm{Ac}$ \\
\hline & & Permeable & $100 \mathrm{Aa}$ & $94 \mathrm{Ab}$ & $12 \mathrm{Bc}$ \\
\hline & \multirow{2}{*}{$25^{\circ} \mathrm{C} / 50 \%$} & Impermeable & $100 \mathrm{Aa}$ & $94 \mathrm{Ab}$ & $22 \mathrm{Bc}$ \\
\hline & & Permeable & $100 \mathrm{Aa}$ & $96 \mathrm{Ab}$ & $32 \mathrm{Ac}$ \\
\hline & \multirow{2}{*}{$30{ }^{\circ} \mathrm{C} / 40 \%$} & Impermeable & $100 \mathrm{Aa}$ & $96 \mathrm{Ab}$ & $14 \mathrm{Ac}$ \\
\hline & & Permeable & $100 \mathrm{Aa}$ & $\mathbf{0} \mathbf{B b}$ & $\mathbf{0} \mathbf{B b}$ \\
\hline \multirow{6}{*}{$55^{\circ} \mathrm{C}$} & \multirow{2}{*}{$20{ }^{\circ} \mathrm{C} / 60 \%$} & Impermeable & $94 \mathrm{Aa}$ & $82 \mathrm{Bb}$ & $20 \mathrm{Ac}$ \\
\hline & & Permeable & $94 \mathrm{Ab}$ & $100 \mathrm{Aa}$ & $8 \mathrm{Bc}$ \\
\hline & \multirow{2}{*}{$25^{\circ} \mathrm{C} / \mathbf{5 0} \%$} & Impermeable & $94 \mathrm{Ab}$ & $100 \mathrm{Aa}$ & $17 \mathrm{Bc}$ \\
\hline & & Permeable & 94 Aa & $96 \mathrm{Ba}$ & $32 \mathrm{Ac}$ \\
\hline & \multirow{2}{*}{$30{ }^{\circ} \mathrm{C} / 40 \%$} & Impermeável & $94 \mathrm{Ab}$ & $100 \mathrm{Aa}$ & O Ac \\
\hline & & Permeable & 94 Aa & $\mathbf{0} \mathbf{B b}$ & 0 Ac \\
\hline \multirow{6}{*}{$65^{\circ} \mathrm{C}$} & \multirow{2}{*}{$20^{\circ} \mathrm{C} / 60 \%$} & Impermeable & $78 \mathrm{Ab}$ & $82 \mathrm{Ba}$ & $41 \mathrm{Ac}$ \\
\hline & & Permeable & $78 \mathrm{Ab}$ & 96 Aa & $19 \mathrm{Bc}$ \\
\hline & \multirow{2}{*}{$25^{\circ} \mathrm{C} / \mathbf{5 0} \%$} & Impermeável & $78 \mathrm{Ab}$ & $88 \mathrm{Ba}$ & $30 \mathrm{Ac}$ \\
\hline & & Permeável & $78 \mathrm{Ab}$ & 96 Aa & $26 \mathrm{Bc}$ \\
\hline & \multirow{2}{*}{$30{ }^{\circ} \mathrm{C} / 40 \%$} & Impermeable & $78 \mathrm{Ab}$ & $96 \mathrm{Aa}$ & $37 \mathrm{Ac}$ \\
\hline & & Permeable & $78 \mathrm{Aa}$ & $\mathbf{0} \mathbf{B b}$ & $\mathbf{0} \mathbf{B b}$ \\
\hline \multirow{6}{*}{$75^{\circ} \mathrm{C}$} & \multirow{2}{*}{$20{ }^{\circ} \mathrm{C} / 60 \%$} & Impermeable & 84 Aa & $86 \mathrm{Ba}$ & $31 \mathrm{Ab}$ \\
\hline & & Permeable & $84 \mathrm{Ab}$ & 96 Aa & $21 \mathrm{Bc}$ \\
\hline & \multirow{2}{*}{$25^{\circ} \mathrm{C} / \mathbf{5 0} \%$} & Impermeable & $84 \mathrm{Ab}$ & $100 \mathrm{Aa}$ & $28 \mathrm{Ac}$ \\
\hline & & Permeable & $84 \mathrm{Ab}$ & $96 \mathrm{Ba}$ & $0 \mathrm{Bc}$ \\
\hline & \multirow{2}{*}{$30{ }^{\circ} \mathrm{C} / 40 \%$} & Impermeable & $84 \mathrm{Ab}$ & 92 Aa & $45 \mathrm{Ac}$ \\
\hline & & Permeable & 84 Aa & $\mathbf{0} \mathbf{B b}$ & $\mathbf{0} \mathbf{B b}$ \\
\hline
\end{tabular}

Means followed by the capital letter in the column for each package and lower lines for each storage time, do not differ at $5 \%$ probability. Coefficient of variation $(\mathrm{CV})=6.44 \%$

conditions of $20{ }^{\circ} \mathrm{C}$ and $60 \% \mathrm{RH}$ air showed better results for the germination of seeds (Tables 1, 2 and 3). Almeida et al. (2010) observed a linear decrease in germination of five oilseed species (cotton, peanut, soybean, sunflower and castor), with increasing period of storage in ambient conditions, data that agree with those obtained by Fessel et al. (2010), who stated that the physiological quality (germination and vigor) of rice seeds, corn and beans has decreased throughout the storage period.

According to Carvalho and Nakagawa (2000) seeds have a higher germination and vigor during the physiological maturation. From this moment, occur inevitably gradual physiological and biochemical changes that cause deterioration and gradual loss of vigor. According to Tonin and Perez (2006) seed quality is extremely important factor in order to obtain productivity. Packaging used in storage should help slow the deterioration process, keeping the initial water content of stored seeds, in order to decrease the breathing. Thus, we observed a $100 \%$ reduction in the germination of seeds stored in permeable packaging conditions of $30{ }^{\circ} \mathrm{C}$ and $40 \% \mathrm{RH}$ air. There was also a significant difference $(\mathrm{p}<0.05)$, in relation to germination between seeds stored in permeable and impermeable packaging and have gone through the drying process at temperatures above $45{ }^{\circ} \mathrm{C}$. The percentage of germinated seeds was higher in waterproof packaging. According to Marcos Filho (2005) the deterioration of seeds is associated with the characteristics of the containers thereof, depending on the greater or lesser facility for the exchange of water vapor between the seeds and the atmosphere and the environmental conditions under which they remain stored.

Similar results were observed with germination with accelerated aging of sunflower seeds (Table 4). The drying temperatures of 45 and $65^{\circ} \mathrm{C}$ less affected the quality of the seeds, and storage conditions of $20{ }^{\circ} \mathrm{C}$ and $60 \%, 25{ }^{\circ} \mathrm{C}$ and $50 \%$ were the best for the conservation of seeds, regardless of the type of packaging (Tables 5, 6 and 7).

Results in accelerated aging storage of sunflower seeds in permeable and impermeable packaging, it was observed that there were significant variations $(\mathrm{P}<0.05)$ quality (Table 6), in which the permeable packaging had higher percentages of seeds germinated. This can be explained since the seeds to pass through the stress and the drying are packed in closed environments to reduce the breathing process that could increase the intergranular stress further increasing of deterioration, unlike the seeds stored in permeable packaging which would 
Table 4. Accelerated aging of sunflower seeds (\%) versus temperature air drying and storage conditions for each type of packaging and storage time.

\begin{tabular}{|c|c|c|c|c|c|c|}
\hline \multirow{2}{*}{$\begin{array}{l}\text { Storage time } \\
\text { (months) }\end{array}$} & \multirow{2}{*}{ Packing } & \multirow{2}{*}{$\begin{array}{c}\text { Storage } \\
\text { conditions }\end{array}$} & \multicolumn{4}{|c|}{ Temperature of the drying air } \\
\hline & & & $45^{\circ} \mathrm{C}$ & $55^{\circ} \mathrm{C}$ & $65^{\circ} \mathrm{C}$ & $75^{\circ} \mathrm{C}$ \\
\hline $\mathbf{0}$ & - & - & $92 \mathrm{~b}$ & $96 \mathbf{a}$ & $92 \mathrm{~b}$ & $98 \mathbf{a}$ \\
\hline \multirow{6}{*}{3} & \multirow{3}{*}{ Impermeable } & $20{ }^{\circ} \mathrm{C} / 60 \%$ & $90 \mathrm{Aa}$ & $82 \mathrm{Bb}$ & 52 Bd & $70 \mathrm{Bc}$ \\
\hline & & $25^{\circ} \mathrm{C} / 50 \%$ & $76 \mathrm{Ba}$ & $64 \mathrm{Cc}$ & $70 \mathrm{Ab}$ & $60 \mathrm{Cc}$ \\
\hline & & $30{ }^{\circ} \mathrm{C} / 40 \%$ & $78 \mathrm{Bc}$ & 96 Aa & 72 Ad & $82 \mathrm{Ab}$ \\
\hline & \multirow{3}{*}{ Permeable } & $20{ }^{\circ} \mathrm{C} / 60 \%$ & $86 \mathrm{Ba}$ & 86 Aa & $68 \mathrm{Bb}$ & $68 \mathrm{Bb}$ \\
\hline & & $25^{\circ} \mathrm{C} / 50 \%$ & 96 Aa & 82 Bc & $92 \mathrm{Ab}$ & $90 \mathrm{Ab}$ \\
\hline & & $30{ }^{\circ} \mathrm{C} / 40 \%$ & $0 \mathrm{Ca}$ & $0 \mathbf{C a}$ & $0 \mathrm{Ca}$ & $0 \mathrm{Ca}$ \\
\hline \multirow{6}{*}{6} & \multirow{4}{*}{ Impermeable } & $20{ }^{\circ} \mathrm{C} / 60 \%$ & $34 \mathrm{Bb}$ & $32 \mathrm{Bb}$ & 37 Aa & $36 \mathrm{Ba}$ \\
\hline & & $25^{\circ} \mathrm{C} / 50 \%$ & 39 Aa & 37 Aa & $36 \mathbf{A b}$ & $34 \mathrm{Bb}$ \\
\hline & & $30{ }^{\circ} \mathrm{C} / 40 \%$ & $7 \mathbf{C b}$ & $0 \mathrm{Cc}$ & 35 Aa & 42 Aa \\
\hline & & $20{ }^{\circ} \mathrm{C} / 60 \%$ & 36 Aa & $31 \mathrm{Ab}$ & $30 \mathbf{A b}$ & $29 \mathrm{Ab}$ \\
\hline & \multirow[t]{2}{*}{ Permeable } & $25^{\circ} \mathrm{C} / 50 \%$ & $32 \mathrm{Ba}$ & $31 \mathrm{Aa}$ & $33 \mathrm{Aa}$ & $\mathbf{0} \mathbf{B b}$ \\
\hline & & $30{ }^{\circ} \mathrm{C} / 40 \%$ & $0 \mathbf{C a}$ & $0 \mathbf{B a}$ & $\mathbf{0} \mathbf{B a}$ & $0 \mathbf{B a}$ \\
\hline
\end{tabular}

Means followed by the capital letter in the column for each storage condition and lower lines for each temperature of the drying air, do not differ at $5 \%$ probability. Coefficient of variation $(\mathrm{CV})=5.36 \%$.

Table 5. Accelerated aging of sunflower seeds (\%) according to the drying air temperature and time of storage for each type of packaging and storage conditions.

\begin{tabular}{|c|c|c|c|c|c|c|}
\hline \multirow{2}{*}{$\begin{array}{l}\text { Storage time } \\
\text { (months) }\end{array}$} & \multirow{2}{*}{ Packing } & \multirow{2}{*}{$\begin{array}{c}\text { Storage } \\
\text { conditions }\end{array}$} & \multicolumn{4}{|c|}{ Temperature of the drying air } \\
\hline & & & $45^{\circ} \mathrm{C}$ & $55^{\circ} \mathrm{C}$ & $65^{\circ} \mathrm{C}$ & $75^{\circ} \mathrm{C}$ \\
\hline $\mathbf{0}$ & \multirow{3}{*}{ Impermeable } & - & $92 \mathbf{A b}$ & 96 Aa & $92 \mathbf{A b}$ & $98 \mathrm{Aa}$ \\
\hline 3 & & $20{ }^{\circ} \mathrm{C} / 60 \%$ & 90 Aa & $82 \mathrm{Ab}$ & $52 \mathrm{Bd}$ & $70 \mathrm{Bc}$ \\
\hline 6 & & $20{ }^{\circ} \mathrm{C} / 60 \%$ & $34 \mathrm{Bb}$ & $32 \mathrm{Bb}$ & $37 \mathrm{Ca}$ & $36 \mathrm{Ca}$ \\
\hline $\mathbf{0}$ & \multirow{3}{*}{ Permeable } & - & $92 \mathrm{Ab}$ & 96 Aa & $92 \mathrm{Ab}$ & 98 Aa \\
\hline 3 & & $20{ }^{\circ} \mathrm{C} / 60 \%$ & $86 \mathrm{Ba}$ & $86 \mathrm{Ba}$ & $68 \mathrm{Bb}$ & $68 \mathrm{Bb}$ \\
\hline 6 & & $20{ }^{\circ} \mathrm{C} / 60 \%$ & $36 \mathrm{Ca}$ & $31 \mathrm{Cb}$ & $30 \mathbf{C b}$ & $29 \mathrm{Cb}$ \\
\hline $\mathbf{0}$ & \multirow{3}{*}{ Impermeable } & - & $92 \mathbf{A b}$ & 96 Aa & $92 \mathbf{A b}$ & $98 \mathrm{Aa}$ \\
\hline 3 & & $25^{\circ} \mathrm{C} / 50 \%$ & $76 \mathbf{B a}$ & $64 \mathrm{Bc}$ & $70 \mathrm{Bb}$ & $60 \mathrm{Bc}$ \\
\hline 6 & & $25^{\circ} \mathrm{C} / 50 \%$ & $39 \mathrm{Ca}$ & $37 \mathbf{C b}$ & $36 \mathrm{Cb}$ & $34 \mathrm{Cb}$ \\
\hline $\mathbf{0}$ & \multirow{3}{*}{ Permeable } & - & $92 \mathrm{Bb}$ & 96 Аa & $92 \mathbf{A b}$ & $98 \mathrm{Aa}$ \\
\hline 3 & & $25^{\circ} \mathrm{C} / 50 \%$ & 96 Aa & 82 Bc & $92 \mathbf{A b}$ & $90 \mathrm{Bc}$ \\
\hline 6 & & $25^{\circ} \mathrm{C} / 50 \%$ & $32 \mathrm{Ca}$ & $31 \mathrm{Ca}$ & $33 \mathrm{Ca}$ & $0 \mathbf{C b}$ \\
\hline $\mathbf{0}$ & \multirow{3}{*}{ Impermeable } & - & $92 \mathbf{A b}$ & 96 Aa & $92 \mathrm{Ab}$ & $98 \mathrm{Aa}$ \\
\hline 3 & & $30{ }^{\circ} \mathrm{C} / 40 \%$ & $78 \mathrm{Bc}$ & 96 Aa & $72 \mathrm{Bd}$ & $82 \mathrm{Bb}$ \\
\hline 6 & & $30{ }^{\circ} \mathrm{C} / 40 \%$ & $7 \mathrm{Cc}$ & 0 Bd & $35 \mathrm{Cb}$ & $42 \mathrm{Ca}$ \\
\hline $\mathbf{0}$ & \multirow{3}{*}{ Permeable } & - & $92 \mathrm{Ac}$ & $96 \mathrm{Ab}$ & 92 Ac & $98 \mathrm{Aa}$ \\
\hline 3 & & $30{ }^{\circ} \mathrm{C} / 40 \%$ & $\mathbf{0} \mathbf{B a}$ & $\mathbf{0} \mathbf{B a}$ & $\mathbf{0} \mathbf{B a}$ & $0 \mathbf{B a}$ \\
\hline 6 & & $30{ }^{\circ} \mathrm{C} / 40 \%$ & $\mathbf{0} \mathbf{B a}$ & $0 \mathbf{B a}$ & $0 \mathbf{B a}$ & $0 \mathbf{B a}$ \\
\hline
\end{tabular}

Means followed by the capital letter in the column for each storage time and lower lines for each temperature of the drying air, do not differ at $5 \%$ probability. Coefficient of variation $(\mathrm{CV})=4.91 \%$.

react with the moist environment, encouraging the exchange of water vapor between the seeds and the atmosphere, increasing the percentage of germination.

According to Marcos Filho (2005), seed deterioration is associated with the characteristics of the containers thereof, depending of the facility in the exchange of water vapor between the atmosphere and the seeds and the conditions of the environment in which same remain stored.
The time (Table 5) along with the storage conditions were the major variables that interfere in seed quality analysis in accelerated aging of seeds, with significant results for all treatments. In permeable packaging stored and conditions of $30{ }^{\circ} \mathrm{C}$ and $40 \% \mathrm{RH}$ air, it was observed significant reduction in the germination of seeds from the three months of storage.

Storage is critical to the maintenance of seed quality practice, and a method by which you can preserve the viability of the 
Table 6. Accelerated aging of sunflower seeds (\%) versus time of storage and the type of packaging for each of the drying air temperature and storage condition.

\begin{tabular}{|c|c|c|c|c|c|}
\hline \multirow{2}{*}{$\begin{array}{l}\text { Drying air } \\
\text { temperature }\end{array}$} & \multirow{2}{*}{$\begin{array}{c}\text { Storage } \\
\text { conditions }\end{array}$} & \multirow{2}{*}{ Packing } & \multicolumn{3}{|c|}{ Time of storage (months) } \\
\hline & & & $\mathbf{0}$ & 3 & 6 \\
\hline \multirow{6}{*}{$45^{\circ} \mathrm{C}$} & \multirow{2}{*}{$20{ }^{\circ} \mathrm{C} / 60 \%$} & Impermeable & 92 Aa & $90 \mathrm{Aa}$ & $34 \mathrm{Ab}$ \\
\hline & & Permeable & $92 \mathrm{Aa}$ & $86 \mathrm{Ba}$ & $36 \mathrm{Ab}$ \\
\hline & \multirow{2}{*}{$25^{\circ} \mathrm{C} / 50 \%$} & Impermeable & 92 Aa & $76 \mathrm{Bb}$ & $39 \mathbf{A b}$ \\
\hline & & Permeable & 92 Aa & 96 Aa & $32 \mathbf{B b}$ \\
\hline & \multirow{2}{*}{$30{ }^{\circ} \mathrm{C} / 40 \%$} & Impermeable & 92 Aa & $78 \mathrm{Ab}$ & $7 \mathrm{Ac}$ \\
\hline & & Permeable & 92 Aa & $\mathbf{0} \mathbf{B b}$ & $\mathbf{0} \mathbf{B b}$ \\
\hline \multirow{6}{*}{$55^{\circ} \mathrm{C}$} & \multirow{2}{*}{$20{ }^{\circ} \mathrm{C} / 60 \%$} & Impermeable & 96 Aa & 82 Bb & 32 Ac \\
\hline & & Permeable & 96 Aa & $86 \mathrm{Ab}$ & $31 \mathrm{Ac}$ \\
\hline & \multirow{2}{*}{$25^{\circ} \mathrm{C} / 50 \%$} & Impermeable & 96 Aa & $64 \mathrm{Bb}$ & 37 Ac \\
\hline & & Permeable & 96 Aa & $82 \mathrm{Ab}$ & $31 \mathrm{Bc}$ \\
\hline & \multirow{2}{*}{$30{ }^{\circ} \mathrm{C} / 40 \%$} & Impermeável & 96 Aa & 96 Aa & $\mathbf{0} \mathbf{A b}$ \\
\hline & & Permeable & 96 Aa & $\mathbf{0} \mathbf{B b}$ & $\mathbf{0} \mathbf{A b}$ \\
\hline \multirow{6}{*}{$65^{\circ} \mathrm{C}$} & \multirow{2}{*}{$20{ }^{\circ} \mathrm{C} / 60 \%$} & Impermeable & 92 Aa & $52 \mathrm{Ab}$ & $37 \mathrm{Ac}$ \\
\hline & & Permeable & 92 Aa & $68 \mathrm{Ab}$ & $30 \mathrm{Bc}$ \\
\hline & \multirow{2}{*}{$25^{\circ} \mathrm{C} / 50 \%$} & Impermeável & 92 Aa & $70 \mathbf{B b}$ & $36 \mathrm{Ac}$ \\
\hline & & Permeável & $92 \mathrm{Aa}$ & $92 \mathrm{Aa}$ & $33 \mathrm{Bb}$ \\
\hline & \multirow{2}{*}{$30{ }^{\circ} \mathrm{C} / 40 \%$} & Impermeable & $92 \mathrm{Aa}$ & $72 \mathrm{Ab}$ & $35 \mathrm{Ac}$ \\
\hline & & Permeable & 92 Aa & $\mathbf{0} \mathbf{B b}$ & $\mathbf{0} \mathbf{B b}$ \\
\hline \multirow{6}{*}{$75^{\circ} \mathrm{C}$} & \multirow{2}{*}{$20{ }^{\circ} \mathrm{C} / 60 \%$} & Impermeable & 98 Aa & $70 \mathrm{Ab}$ & $36 \mathrm{Ac}$ \\
\hline & & Permeable & $98 \mathrm{Aa}$ & $68 \mathrm{Ab}$ & $29 \mathrm{Bc}$ \\
\hline & \multirow{2}{*}{$25^{\circ} \mathrm{C} / 50 \%$} & Impermeable & $98 \mathrm{Aa}$ & $60 \mathrm{Bb}$ & $34 \mathrm{Ac}$ \\
\hline & & Permeable & $98 \mathrm{Aa}$ & $90 \mathrm{Ab}$ & $\mathbf{0} \mathrm{Ac}$ \\
\hline & \multirow{2}{*}{$30{ }^{\circ} \mathrm{C} / 40 \%$} & Impermeable & 98 Aa & $82 \mathrm{Ab}$ & $42 \mathrm{Ac}$ \\
\hline & & Permeable & $98 \mathrm{Aa}$ & $\mathbf{0} \mathbf{B b}$ & 0 B b \\
\hline
\end{tabular}

Means followed by the capital letter in the column for each package and lower lines for each storage time, do not differ at $5 \%$ probability. Coefficient of variation $(\mathrm{CV})=8.10 \%$.

Table 7. Speed index emergence of sunflower seeds (\%) in function of air drying temperature and storage conditions for each type of packaging and storage time.

\begin{tabular}{|c|c|c|c|c|c|c|}
\hline \multirow{2}{*}{$\begin{array}{l}\text { Storage time } \\
\text { (months) }\end{array}$} & \multirow{2}{*}{ Packing } & \multirow{2}{*}{$\begin{array}{c}\text { Storage } \\
\text { conditions }\end{array}$} & \multicolumn{4}{|c|}{ Temperature of the drying air } \\
\hline & & & $45^{\circ} \mathrm{C}$ & $55^{\circ} \mathrm{C}$ & $65^{\circ} \mathrm{C}$ & $75^{\circ} \mathrm{C}$ \\
\hline $\mathbf{0}$ & - & - & $2.07 \mathrm{c}$ & $2.36 \mathrm{~b}$ & $1.49 \mathrm{~d}$ & $2.03 \mathrm{a}$ \\
\hline \multirow{6}{*}{3} & \multirow{3}{*}{ Impermeable } & $20{ }^{\circ} \mathrm{C} / 60 \%$ & $0.79 \mathrm{Ab}$ & $0.78 \mathrm{Ab}$ & $0.34 \mathrm{Bc}$ & $1.86 \mathrm{Ba}$ \\
\hline & & $25^{\circ} \mathrm{C} / 50 \%$ & $0.81 \mathrm{Ac}$ & $0.79 \mathrm{Ac}$ & $2.45 \mathrm{Aa}$ & $2.04 \mathrm{Ab}$ \\
\hline & & $30{ }^{\circ} \mathrm{C} / 40 \%$ & $\mathbf{0} \mathbf{B a}$ & $0 \mathrm{Ba}$ & $0 \mathrm{Ca}$ & $0 \mathrm{Ca}$ \\
\hline & \multirow{3}{*}{ Permeable } & $20{ }^{\circ} \mathrm{C} / 60 \%$ & $0.81 \mathrm{Ba}$ & $0.81 \mathrm{Ba}$ & $0.82 \mathrm{Ba}$ & $0.78 \mathrm{Ba}$ \\
\hline & & $25^{\circ} \mathrm{C} / 50 \%$ & $2.36 \mathrm{Aa}$ & $2.39 \mathrm{Aa}$ & $2.36 \mathrm{Aa}$ & $2.46 \mathrm{Aa}$ \\
\hline & & $30{ }^{\circ} \mathrm{C} / 40 \%$ & $0 \mathrm{Ca}$ & $\mathbf{0} \mathbf{C a}$ & $0 \mathrm{Ca}$ & $0 \mathbf{C a}$ \\
\hline \multirow{6}{*}{6} & \multirow{3}{*}{ Impermeable } & $20{ }^{\circ} \mathrm{C} / 60 \%$ & $0.80 \mathrm{Aa}$ & $0.81 \mathrm{Aa}$ & $0.81 \mathrm{Ba}$ & $0.77 \mathrm{Bb}$ \\
\hline & & $25^{\circ} \mathrm{C} / 50 \%$ & $0.75 \mathrm{Bc}$ & $0.65 \mathrm{Bd}$ & $1.45 \mathrm{Ab}$ & $1.90 \mathrm{Aa}$ \\
\hline & & $30{ }^{\circ} \mathrm{C} / 40 \%$ & $\mathbf{0} \mathbf{C a}$ & $\mathbf{0} \mathbf{C a}$ & $0 \mathrm{Ca}$ & $0 \mathrm{Ca}$ \\
\hline & \multirow{3}{*}{ Permeable } & $20^{\circ} \mathrm{C} / 60 \%$ & $0.65 \mathrm{Ba}$ & $0.60 \mathrm{Ba}$ & $0.54 \mathrm{Bb}$ & $0.48 \mathrm{Bc}$ \\
\hline & & $25^{\circ} \mathrm{C} / 50 \%$ & $1.82 \mathrm{Aa}$ & $1.71 \mathrm{Ab}$ & $1.16 \mathrm{Ac}$ & $1.10 \mathrm{Ad}$ \\
\hline & & $30{ }^{\circ} \mathrm{C} / 40 \%$ & $0 \mathrm{Ca}$ & $0 \mathrm{Ca}$ & $0 \mathrm{Ca}$ & $0 \mathrm{Ca}$ \\
\hline
\end{tabular}

Means followed by the capital letter in the column for each storage condition and lower lines for each temperature of the drying air, do not differ at $5 \%$ probability. Coefficient of variation $(\mathrm{CV})=6.80 \%$. 
Table 8. Speed index emergence of sunflower seeds (\%) in function of air drying temperature and storage time for each type of packaging and storage condition.

\begin{tabular}{|c|c|c|c|c|c|c|}
\hline \multirow{2}{*}{$\begin{array}{l}\text { Storage time } \\
\text { (months) }\end{array}$} & \multirow{2}{*}{ Packing } & \multirow{2}{*}{$\begin{array}{c}\text { Storage } \\
\text { conditions }\end{array}$} & \multicolumn{4}{|c|}{ Temperature of the drying air } \\
\hline & & & $45^{\circ} \mathrm{C}$ & $55^{\circ} \mathrm{C}$ & $65^{\circ} \mathrm{C}$ & $75^{\circ} \mathrm{C}$ \\
\hline $\mathbf{0}$ & & - & $2.07 \mathrm{Ab}$ & $2.36 \mathrm{Aa}$ & $1.49 \mathrm{Ac}$ & $2.03 \mathrm{Ab}$ \\
\hline 3 & Impermeable & $20^{\circ} \mathrm{C} / 60 \%$ & $0.79 \mathrm{Bb}$ & $0.78 \mathrm{Bb}$ & $0.34 \mathrm{Cc}$ & $1.86 \mathrm{Ba}$ \\
\hline 6 & & $20{ }^{\circ} \mathrm{C} / 60 \%$ & $0.80 \mathrm{Ba}$ & $0.81 \mathrm{Ba}$ & $0.81 \mathrm{Ba}$ & $0.77 \mathrm{Ca}$ \\
\hline $\mathbf{0}$ & & - & 2.07 Ac & $2.36 \mathrm{Ab}$ & 1.49 Ad & $2.03 \mathrm{Aa}$ \\
\hline 3 & Permeable & $20{ }^{\circ} \mathrm{C} / 60 \%$ & $0.81 \mathrm{Ba}$ & $0.81 \mathrm{Ba}$ & $0.82 \mathrm{Ba}$ & $0.78 \mathrm{Ba}$ \\
\hline 6 & & $20{ }^{\circ} \mathrm{C} / 60 \%$ & $0.65 \mathrm{Ca}$ & $0.60 \mathrm{Cb}$ & $0.54 \mathrm{Cc}$ & $0.48 \mathrm{Cc}$ \\
\hline $\mathbf{0}$ & & - & $2.07 \mathrm{Ab}$ & $2.36 \mathrm{Aa}$ & $1.49 \mathrm{Bc}$ & $2.03 \mathrm{Ab}$ \\
\hline 3 & Impermeable & $25^{\circ} \mathrm{C} / 50 \%$ & $0.81 \mathrm{Bc}$ & $0.79 \mathrm{Bc}$ & $2.45 \mathrm{Aa}$ & $2.04 \mathrm{Ab}$ \\
\hline 6 & & $25^{\circ} \mathrm{C} / \mathbf{5 0} \%$ & $0.75 \mathrm{Cc}$ & $0.65 \mathrm{Cd}$ & $1.45 \mathrm{Bb}$ & $1.90 \mathrm{Ba}$ \\
\hline $\mathbf{0}$ & & - & $2.07 \mathrm{Bb}$ & $2.36 \mathrm{Aa}$ & $1.49 \mathrm{Bc}$ & $2.03 \mathrm{Cb}$ \\
\hline 3 & Permeable & $25{ }^{\circ} \mathrm{C} / 50 \%$ & $2.36 \mathrm{Ab}$ & $2.39 \mathrm{Ab}$ & $2.36 \mathrm{Ab}$ & $2.46 \mathrm{Aa}$ \\
\hline 6 & & $25^{\circ} \mathrm{C} / \mathbf{5 0} \%$ & $1.82 \mathrm{Ca}$ & $1.71 \mathrm{Ba}$ & $1.16 \mathrm{Cb}$ & $1.10 \mathrm{Bb}$ \\
\hline $\mathbf{0}$ & & - & $2.07 \mathrm{Ab}$ & $2.36 \mathrm{Aa}$ & $1.49 \mathrm{Ac}$ & $2.03 \mathrm{Ab}$ \\
\hline 3 & Impermeable & $30{ }^{\circ} \mathrm{C} / 40 \%$ & $0 \mathrm{Ba}$ & O Ba & O Ba & O Ba \\
\hline 6 & & $30{ }^{\circ} \mathrm{C} / 40 \%$ & $0 \mathrm{Ba}$ & $0 \mathrm{Ba}$ & $0 \mathrm{Ba}$ & $0 \mathrm{Ba}$ \\
\hline $\mathbf{0}$ & & - & 2.07 Ab & $2.36 \mathrm{Aa}$ & $1.49 \mathrm{Ac}$ & $2.03 \mathrm{Ab}$ \\
\hline 3 & Permeable & $30{ }^{\circ} \mathrm{C} / 40 \%$ & $0 \mathrm{Ba}$ & $0 \mathrm{Ba}$ & $0 \mathrm{Ba}$ & $0 \mathrm{Ba}$ \\
\hline 6 & & $30{ }^{\circ} \mathrm{C} / 40 \%$ & O Ba & $0 \mathrm{Ba}$ & $0 \mathrm{Ba}$ & $0 \mathbf{B a}$ \\
\hline
\end{tabular}

Means followed by the capital letter in the column for each storage time and lower lines for each temperature of the drying air, do not differ at $5 \%$ probability. Coefficient of variation $(\mathrm{CV})=5.34 \%$.

Table 9. Speed index emergence of sunflower seeds (\%) versus time of storage and the type of packaging for each air temperature drying and storage condition.

\begin{tabular}{|c|c|c|c|c|c|}
\hline \multirow{2}{*}{$\begin{array}{l}\text { Drying air } \\
\text { temperature }\end{array}$} & \multirow{2}{*}{$\begin{array}{c}\text { Storage } \\
\text { conditions }\end{array}$} & \multirow{2}{*}{ Packing } & \multicolumn{3}{|c|}{ Time of storage (months) } \\
\hline & & & $\mathbf{0}$ & 3 & 6 \\
\hline \multirow{6}{*}{$45^{\circ} \mathrm{C}$} & \multirow{2}{*}{$20{ }^{\circ} \mathrm{C} / 60 \%$} & Impermeable & $2.07 \mathrm{Aa}$ & $0.79 \mathrm{Ab}$ & $0.80 \mathrm{Ab}$ \\
\hline & & Permeable & $2.07 \mathrm{Aa}$ & $0.81 \mathrm{Ab}$ & $0.65 \mathrm{Bc}$ \\
\hline & \multirow{2}{*}{$25^{\circ} \mathrm{C} / 50 \%$} & Impermeable & $2.07 \mathrm{Aa}$ & $0.81 \mathrm{Bb}$ & $0.75 \mathrm{Bc}$ \\
\hline & & Permeable & $2.07 \mathrm{Ab}$ & $2.36 \mathrm{Aa}$ & $1.82 \mathrm{Ac}$ \\
\hline & \multirow{2}{*}{$30{ }^{\circ} \mathrm{C} / 40 \%$} & Impermeable & $2.07 \mathrm{Aa}$ & $\mathbf{0} \mathbf{A b}$ & $\mathbf{0} \mathbf{A b}$ \\
\hline & & Permeable & 2.07 Aa & $\mathbf{0} \mathbf{A b}$ & $\mathbf{0} \mathbf{A b}$ \\
\hline \multirow{6}{*}{$55^{\circ} \mathrm{C}$} & \multirow{2}{*}{$20^{\circ} \mathrm{C} / 60 \%$} & Impermeable & $2.36 \mathrm{Aa}$ & $0.78 \mathrm{Ab}$ & $0.81 \mathrm{Ab}$ \\
\hline & & Permeable & $2.36 \mathrm{Aa}$ & $0.81 \mathrm{Ab}$ & $0.60 \mathrm{Bc}$ \\
\hline & \multirow{2}{*}{$25^{\circ} \mathrm{C} / 50 \%$} & Impermeable & $2.36 \mathrm{Aa}$ & $0.79 \mathrm{Bb}$ & $0.65 \mathrm{Bc}$ \\
\hline & & Permeable & $2.36 \mathrm{Aa}$ & $2.39 \mathrm{Aa}$ & $1.71 \mathrm{Ab}$ \\
\hline & \multirow{2}{*}{$30{ }^{\circ} \mathrm{C} / 40 \%$} & Impermeável & $2.36 \mathrm{Aa}$ & $\mathbf{0} \mathbf{A b}$ & $\mathbf{0} \mathbf{A b}$ \\
\hline & & Permeable & $2.36 \mathrm{Aa}$ & $\mathbf{0} \mathbf{A b}$ & $\mathbf{0} \mathbf{A b}$ \\
\hline \multirow{6}{*}{$65^{\circ} \mathrm{C}$} & \multirow{2}{*}{$20{ }^{\circ} \mathrm{C} / 60 \%$} & Impermeable & $1.49 \mathrm{Aa}$ & $0.34 \mathrm{Bc}$ & $0.81 \mathrm{Ab}$ \\
\hline & & Permeable & $1.49 \mathrm{Aa}$ & $0.82 \mathrm{Ab}$ & $0.54 \mathrm{Bc}$ \\
\hline & \multirow{2}{*}{$25^{\circ} \mathrm{C} / 50 \%$} & Impermeável & $1.49 \mathrm{Ab}$ & $2.45 \mathrm{Aa}$ & $1.45 \mathrm{Ab}$ \\
\hline & & Permeável & $1.49 \mathrm{Ab}$ & $2.36 \mathrm{Ba}$ & $1.16 \mathrm{Bc}$ \\
\hline & \multirow{2}{*}{$30{ }^{\circ} \mathrm{C} / 40 \%$} & Impermeable & $1.49 \mathrm{Aa}$ & $\mathbf{0} \mathbf{A b}$ & $\mathbf{0} \mathbf{A b}$ \\
\hline & & Permeable & $1.49 \mathrm{Aa}$ & $\mathbf{0} \mathbf{A b}$ & $\mathbf{0} \mathbf{A b}$ \\
\hline \multirow{6}{*}{$75^{\circ} \mathrm{C}$} & \multirow{2}{*}{$20{ }^{\circ} \mathrm{C} / 60 \%$} & Impermeable & $2.03 \mathrm{Aa}$ & $1.86 \mathrm{Ab}$ & $0.77 \mathrm{Ac}$ \\
\hline & & Permeable & $2.03 \mathrm{Aa}$ & $0.78 \mathrm{Bb}$ & $0.48 \mathrm{Bc}$ \\
\hline & \multirow{2}{*}{$25^{\circ} \mathrm{C} / 50 \%$} & Impermeable & $2.03 \mathrm{Aa}$ & $2.04 \mathrm{Ba}$ & $1.90 \mathrm{Ab}$ \\
\hline & & Permeable & $2.03 \mathrm{Ab}$ & $2.46 \mathrm{Aa}$ & $1.10 \mathrm{Bc}$ \\
\hline & \multirow{2}{*}{$30{ }^{\circ} \mathrm{C} / 40 \%$} & Impermeable & $2.03 \mathrm{Aa}$ & $\mathbf{0} \mathbf{A b}$ & $\mathbf{0} \mathbf{A b}$ \\
\hline & & Permeable & $2.03 \mathrm{Aa}$ & $\mathbf{0} \mathbf{A b}$ & $\mathbf{0} \mathbf{A b}$ \\
\hline
\end{tabular}

Means followed by the capital letter in the column for each package and lower lines for each storage time, do not differ at $5 \%$ probability. Coefficient of variation $(\mathrm{CV})=7.10 \%$. 
seeds and keep your place until the future seeding or marketing (AZEVEDO et al., 2003). Thus, the packaging used for seed storage should help slow the deterioration process, keeping the initial water content of stored seeds, in order to decrease the respiration (TONIN; PEREZ, 2006).

As for seed vigor index determined by the speed of emergence (Table 7) significant difference between the tests, which demonstrates that the emergence rate was affected by the respective treatments, when subjected to periods of storage was observed. Importantly, the emergence rate is an important factor for rapid seedling establishment under field conditions. Seedlings with larger IVE have higher performance and, consequently, greater ability to withstand stresses that perhaps may interfere with the growth and development of the plant. It was found that as did the percentage of germination, germination velocity index (EVI) higher were observed in seeds stored in refrigerated rooms, because the same decrease their respiration rate due to low temperature, keeping your force longer, compared to the other storage conditions. According to Guimarães et al. (2005), herb seeds-of bull reduced the IVE when stored without temperature control and relative humidity.

In general, there is a reduction in speed of emergence (IVE) index as the storage period increases, and this fact more pronounced under conditions of $30{ }^{\circ} \mathrm{C}$ and $40 \% \mathrm{RH}$ and air permeable packaging (Tables 8 and 9). As to seedling length (Table 10) reductions were observed during the storage period. However, these reductions were more evident in the storage conditions of $30^{\circ} \mathrm{C}$ and $40 \% \mathrm{RH}$ air. Seed performance, measured by the length of the shoot and root system showed effect of packaging and packaging storage time (Table 11). The seeds

Table 10. Sunflower seedling growth (\%) according to the drying air temperature and storage conditions for each type of packaging and storage time.

\begin{tabular}{|c|c|c|c|c|c|c|}
\hline \multirow{2}{*}{$\begin{array}{l}\text { Storage time } \\
\text { (months) }\end{array}$} & \multirow{2}{*}{ Packing } & \multirow{2}{*}{$\begin{array}{c}\text { Storage } \\
\text { conditions }\end{array}$} & \multicolumn{4}{|c|}{ Temperature of the drying air } \\
\hline & & & $45^{\circ} \mathrm{C}$ & $55^{\circ} \mathrm{C}$ & $65^{\circ} \mathrm{C}$ & $75^{\circ} \mathrm{C}$ \\
\hline $\mathbf{0}$ & - & - & $7.3 \mathrm{a}$ & $5.8 \mathrm{c}$ & $6.6 \mathrm{~b}$ & $7.0 \mathrm{a}$ \\
\hline \multirow{6}{*}{3} & \multirow{3}{*}{ Impermeable } & $20{ }^{\circ} \mathrm{C} / 60 \%$ & $5.2 \mathrm{Bc}$ & $4.6 \mathrm{Bd}$ & $5.8 \mathrm{Bb}$ & $6.2 \mathrm{Ba}$ \\
\hline & & $25^{\circ} \mathrm{C} / 50 \%$ & $7.1 \mathrm{Aa}$ & $5.6 \mathrm{Ac}$ & $6.4 \mathrm{Ab}$ & $6.8 \mathrm{Ab}$ \\
\hline & & $30{ }^{\circ} \mathrm{C} / 40 \%$ & $0.0 \mathrm{Ca}$ & $0.0 \mathrm{Ca}$ & $0.0 \mathrm{Ca}$ & $0.0 \mathrm{Ca}$ \\
\hline & \multirow{3}{*}{ Permeable } & $20{ }^{\circ} \mathrm{C} / 60 \%$ & $5.3 \mathrm{Ab}$ & $4.8 \mathrm{Bc}$ & $5.3 \mathrm{Bb}$ & $6.2 \mathrm{Ba}$ \\
\hline & & $25^{\circ} \mathrm{C} / \mathbf{5 0 \%}$ & $5.4 \mathrm{Ad}$ & $7.4 \mathrm{Aa}$ & $5.9 \mathrm{Ac}$ & $6.5 \mathrm{Ab}$ \\
\hline & & $30{ }^{\circ} \mathrm{C} / 40 \%$ & $0.0 \mathrm{Ba}$ & $0.0 \mathrm{Ca}$ & $0.0 \mathrm{Ca}$ & $0.0 \mathrm{Ca}$ \\
\hline \multirow{6}{*}{6} & \multirow{3}{*}{ Impermeable } & $20{ }^{\circ} \mathrm{C} / 60 \%$ & $4.8 \mathrm{Bc}$ & $4.6 \mathrm{Bc}$ & $5.2 \mathrm{Bb}$ & $5.7 \mathrm{Ba}$ \\
\hline & & $25^{\circ} \mathrm{C} / 50 \%$ & $6.5 \mathrm{Aa}$ & $4.9 \mathrm{Ac}$ & $5.7 \mathrm{Ab}$ & $6.3 \mathrm{Aa}$ \\
\hline & & $30{ }^{\circ} \mathrm{C} / 40 \%$ & $0.0 \mathrm{Ca}$ & $0.0 \mathrm{Ca}$ & $0.0 \mathrm{Ca}$ & $0.0 \mathrm{Ca}$ \\
\hline & \multirow{3}{*}{ Permeable } & $20^{\circ} \mathrm{C} / 60 \%$ & $4.8 \mathrm{Ab}$ & $4.1 \mathrm{Bc}$ & $4.4 \mathrm{Bc}$ & $5.7 \mathrm{Aa}$ \\
\hline & & $25^{\circ} \mathrm{C} / 50 \%$ & $4.9 \mathrm{Ab}$ & $6.3 \mathrm{Aa}$ & $5.1 \mathrm{Ab}$ & $4.9 \mathrm{Bb}$ \\
\hline & & $30{ }^{\circ} \mathrm{C} / 40 \%$ & $0.0 \mathrm{Ba}$ & $0.0 \mathrm{Ca}$ & $0.0 \mathrm{Ca}$ & $0.0 \mathrm{Ca}$ \\
\hline
\end{tabular}

Means followed by the capital letter in the column for each storage condition and lower lines for each temperature of the drying air, do not differ at $5 \%$ probability. Coefficient of variation $(\mathrm{CV})=4.90 \%$.

Table 11. Sunflower root growth (\%) according to the drying air temperature and storage conditions for each type of packaging and storage time.

\begin{tabular}{|c|c|c|c|c|c|c|}
\hline \multirow{2}{*}{$\begin{array}{l}\text { Storage time } \\
\text { (months) }\end{array}$} & \multirow{2}{*}{ Packing } & \multirow{2}{*}{$\begin{array}{l}\text { Storage } \\
\text { conditions }\end{array}$} & \multicolumn{4}{|c|}{ Temperature of the drying air } \\
\hline & & & $45^{\circ} \mathrm{C}$ & $55^{\circ} \mathrm{C}$ & $65^{\circ} \mathrm{C}$ & $75^{\circ} \mathrm{C}$ \\
\hline $\mathbf{0}$ & - & - & $5.2 \mathrm{c}$ & $5.5 \mathrm{c}$ & $6.8 \mathrm{~b}$ & $7.4 \mathrm{a}$ \\
\hline \multirow{6}{*}{3} & \multirow{4}{*}{ Impermeable } & $20{ }^{\circ} \mathrm{C} / 60 \%$ & $4.1 \mathrm{Ba}$ & 4.1 Ba & $3.6 \mathrm{Bb}$ & $3.5 \mathrm{Bb}$ \\
\hline & & $25^{\circ} \mathrm{C} / 50 \%$ & $6.5 \mathrm{Aa}$ & $4.9 \mathrm{Ab}$ & 6.3 Aa & 6.6 Aa \\
\hline & & $30{ }^{\circ} \mathrm{C} / 40 \%$ & $0.0 \mathrm{Ca}$ & $0.0 \mathrm{Ca}$ & $0.0 \mathrm{Ca}$ & $0.0 \mathrm{Ca}$ \\
\hline & & $20^{\circ} \mathrm{C} / 60 \%$ & $3.0 \mathrm{Bc}$ & $2.7 \mathrm{Bc}$ & $5.8 \mathrm{Bb}$ & $7.0 \mathrm{Aa}$ \\
\hline & \multirow[t]{2}{*}{ Permeable } & $25^{\circ} \mathrm{C} / 50 \%$ & $3.8 \mathrm{Ac}$ & 4.0 Ac & $7.0 \mathrm{Aa}$ & $4.9 \mathrm{Bb}$ \\
\hline & & $30{ }^{\circ} \mathrm{C} / 40 \%$ & $0.0 \mathrm{Ca}$ & $0.0 \mathrm{Ca}$ & $0.0 \mathrm{Ca}$ & $0.0 \mathrm{Ca}$ \\
\hline \multirow{6}{*}{6} & \multirow{3}{*}{ Impermeable } & $20{ }^{\circ} \mathrm{C} / 60 \%$ & $3.8 \mathrm{Ba}$ & $3.2 \mathrm{Bb}$ & $2.8 \mathrm{Bb}$ & $3.0 \mathrm{Bb}$ \\
\hline & & $25^{\circ} \mathrm{C} / 50 \%$ & $5.7 \mathrm{Ab}$ & $4.0 \mathrm{Ac}$ & $5.7 \mathrm{Ab}$ & 6.0 Aa \\
\hline & & $30{ }^{\circ} \mathrm{C} / 40 \%$ & $0.0 \mathrm{Ca}$ & $0.0 \mathrm{Ca}$ & $0.0 \mathrm{Ca}$ & $0.0 \mathrm{Ca}$ \\
\hline & \multirow{3}{*}{ Permeable } & $20{ }^{\circ} \mathrm{C} / 60 \%$ & $2.5 \mathrm{Bc}$ & $2.2 \mathrm{Bc}$ & $4.5 \mathrm{Bb}$ & $6.2 \mathrm{Aa}$ \\
\hline & & $25^{\circ} \mathrm{C} / 50 \%$ & $2.8 \mathrm{Ad}$ & $3.4 \mathrm{Ac}$ & $5.5 \mathrm{Aa}$ & $4.3 \mathrm{Bb}$ \\
\hline & & $30{ }^{\circ} \mathrm{C} / 40 \%$ & $0.0 \mathrm{Ca}$ & $0.0 \mathrm{Ca}$ & $0.0 \mathrm{Ca}$ & $0.0 \mathrm{Ca}$ \\
\hline
\end{tabular}

Means followed by the capital letter in the column for each storage condition and lower lines for each temperature of the drying air, do not differ at $5 \%$ probability. Coefficient of variation $(\mathrm{CV})=3.85 \%$. 
Table 12. Sunflower seedling growth (\%) vs. time of storage and the type of packaging for each of the drying air temperature and storage condition.

\begin{tabular}{|c|c|c|c|c|c|}
\hline \multirow{2}{*}{$\begin{array}{l}\text { Drying air } \\
\text { temperature }\end{array}$} & \multirow{2}{*}{$\begin{array}{c}\text { Storage } \\
\text { conditions }\end{array}$} & \multirow{2}{*}{ Packing } & \multicolumn{3}{|c|}{ Time of storage (months) } \\
\hline & & & 0 & 3 & 6 \\
\hline \multirow{6}{*}{$45^{\circ} \mathrm{C}$} & \multirow{2}{*}{$20^{\circ} \mathrm{C} / 60 \%$} & Impermeable & $7.3 \mathrm{Aa}$ & $5.2 \mathrm{Ab}$ & $4.8 \mathrm{Ac}$ \\
\hline & & Permeable & $7.3 \mathrm{Aa}$ & $5.3 \mathrm{Ab}$ & $4.8 \mathrm{Ac}$ \\
\hline & \multirow{2}{*}{$25^{\circ} \mathrm{C} / 50 \%$} & Impermeable & $7.3 \mathrm{Aa}$ & $7.1 \mathrm{Aa}$ & $6.5 \mathrm{Ab}$ \\
\hline & & Permeable & $7.3 \mathrm{Aa}$ & $5.4 \mathrm{Bb}$ & 4.9 Bc \\
\hline & \multirow{2}{*}{$30{ }^{\circ} \mathrm{C} / 40 \%$} & Impermeable & $7.3 \mathrm{Aa}$ & $0.0 \mathrm{Ab}$ & 0.0 Ab \\
\hline & & Permeable & $7.3 \mathrm{Aa}$ & $0.0 \mathrm{Ab}$ & $0.0 \mathrm{Ab}$ \\
\hline \multirow{6}{*}{$55^{\circ} \mathrm{C}$} & \multirow{2}{*}{$20{ }^{\circ} \mathrm{C} / 60 \%$} & Impermeable & $5.8 \mathrm{Aa}$ & $4.6 \mathrm{Ab}$ & $4.6 \mathrm{Ab}$ \\
\hline & & Permeable & $5.8 \mathrm{Aa}$ & $4.8 \mathrm{Ab}$ & 4.1 Bc \\
\hline & \multirow{2}{*}{$25^{\circ} \mathrm{C} / \mathbf{5 0} \%$} & Impermeable & $5.8 \mathrm{Aa}$ & $5.6 \mathrm{Ba}$ & $4.9 \mathrm{Bb}$ \\
\hline & & Permeable & $5.8 \mathrm{Ac}$ & $7.4 \mathrm{Ba}$ & $6.3 \mathrm{Ab}$ \\
\hline & \multirow{2}{*}{$30{ }^{\circ} \mathrm{C} / 40 \%$} & Impermeável & 5.8 Aa & $0.0 \mathrm{Ab}$ & 0.0 Ab \\
\hline & & Permeable & $5.8 \mathrm{Aa}$ & $0.0 \mathrm{Ab}$ & 0.0 Ab \\
\hline \multirow{6}{*}{$65^{\circ} \mathrm{C}$} & \multirow{2}{*}{$20^{\circ} \mathrm{C} / 60 \%$} & Impermeable & $6.6 \mathrm{Aa}$ & $5.8 \mathrm{Ab}$ & $5.2 \mathrm{Ac}$ \\
\hline & & Permeable & $6.6 \mathrm{Aa}$ & $5.3 \mathrm{Bb}$ & 4.4 Bc \\
\hline & \multirow{2}{*}{$25^{\circ} \mathrm{C} / \mathbf{5 0 \%}$} & Impermeável & $6.6 \mathrm{Aa}$ & $6.4 \mathrm{Aa}$ & $5.7 \mathrm{Ab}$ \\
\hline & & Permeável & 6.6 Aa & $5.9 \mathrm{Bb}$ & $5.1 \mathrm{Bc}$ \\
\hline & \multirow{2}{*}{$30{ }^{\circ} \mathrm{C} / 40 \%$} & Impermeable & 6.6 Aa & $0.0 \mathrm{Ab}$ & 0.0 Ab \\
\hline & & Permeable & 6.6 Aa & $0.0 \mathrm{Ab}$ & $0.0 \mathrm{Ab}$ \\
\hline \multirow{6}{*}{$75^{\circ} \mathrm{C}$} & \multirow{2}{*}{$20^{\circ} \mathrm{C} / 60 \%$} & Impermeable & 7.0 Aa & $6.2 \mathrm{Ab}$ & $5.7 \mathrm{Ac}$ \\
\hline & & Permeable & $7.0 \mathrm{Aa}$ & $6.2 \mathrm{Ab}$ & $5.7 \mathrm{Ac}$ \\
\hline & \multirow{2}{*}{$25^{\circ} \mathrm{C} / 50 \%$} & Impermeable & $7.0 \mathrm{Aa}$ & $6.8 \mathrm{Aa}$ & $6.3 \mathrm{Ac}$ \\
\hline & & Permeable & $7.0 \mathrm{Aa}$ & $6.5 \mathrm{Bb}$ & $4.9 \mathrm{Bc}$ \\
\hline & \multirow{2}{*}{$30{ }^{\circ} \mathrm{C} / 40 \%$} & Impermeable & $7.0 \mathrm{Aa}$ & $0.0 \mathrm{Ab}$ & $0.0 \mathrm{Ab}$ \\
\hline & & Permeable & 7.0 Aa & $0.0 \mathrm{Ab}$ & 0.0 Ab \\
\hline
\end{tabular}

Means followed by the capital letter in the column for each package and lower lines for each storage time, do not differ at $5 \%$ probability. Coefficient of variation $(\mathrm{CV})=7.22 \%$.

Table 13. Sunflower root growth (\%) vs. time of storage and the type of packaging for each of the drying air temperature and storage condition.

\begin{tabular}{|c|c|c|c|c|c|}
\hline \multirow{2}{*}{$\begin{array}{c}\text { Drying air } \\
\text { temperature }\end{array}$} & \multirow{2}{*}{$\begin{array}{c}\text { Storage } \\
\text { conditions }\end{array}$} & \multirow{2}{*}{ Packing } & \multicolumn{3}{|c|}{ Time of storage (months) } \\
\hline & & & $\mathbf{0}$ & 3 & 6 \\
\hline \multirow{6}{*}{$45^{\circ} \mathrm{C}$} & \multirow{2}{*}{$20{ }^{\circ} \mathrm{C} / 60 \%$} & Impermeable & $5.2 \mathrm{Aa}$ & $4.1 \mathrm{Ab}$ & $3.8 \mathrm{Ac}$ \\
\hline & & Permeable & $5.2 \mathrm{Aa}$ & 3.0 Bb & $2.5 \mathrm{Bc}$ \\
\hline & \multirow{2}{*}{$25^{\circ} \mathrm{C} / 50 \%$} & Impermeable & $5.2 \mathrm{Ac}$ & $6.5 \mathrm{Aa}$ & $5.7 \mathrm{Ab}$ \\
\hline & & Permeable & $5.2 \mathrm{Aa}$ & $3.8 \mathrm{Bb}$ & $2.8 \mathrm{Bc}$ \\
\hline & \multirow{2}{*}{$30{ }^{\circ} \mathrm{C} / 40 \%$} & Impermeable & $5.2 \mathrm{Aa}$ & $0.0 \mathrm{Ab}$ & $0.0 \mathrm{Ab}$ \\
\hline & & Permeable & 5.2 Aa & $0.0 \mathrm{Ab}$ & $0.0 \mathrm{Ab}$ \\
\hline \multirow{6}{*}{$55^{\circ} \mathrm{C}$} & \multirow{2}{*}{$20{ }^{\circ} \mathrm{C} / 60 \%$} & Impermeable & $5.5 \mathrm{Aa}$ & $4.1 \mathrm{Ab}$ & $3.2 \mathrm{Ac}$ \\
\hline & & Permeable & $5.5 \mathrm{Aa}$ & $2.7 \mathrm{Bb}$ & $2.2 \mathrm{Bc}$ \\
\hline & \multirow{2}{*}{$25^{\circ} \mathrm{C} / 50 \%$} & Impermeable & $5.5 \mathrm{Aa}$ & $4.9 \mathrm{Ab}$ & $4.0 \mathrm{Ac}$ \\
\hline & & Permeable & $5.5 \mathrm{Aa}$ & 4.0 Bb & $3.4 \mathrm{Bc}$ \\
\hline & \multirow{2}{*}{$30{ }^{\circ} \mathrm{C} / 40 \%$} & Impermeável & $5.5 \mathrm{Aa}$ & $0.0 \mathrm{Ab}$ & $0.0 \mathrm{Ab}$ \\
\hline & & Permeable & $5.5 \mathrm{Aa}$ & $0.0 \mathrm{Bb}$ & $0.0 \mathrm{Ab}$ \\
\hline \multirow{6}{*}{$65^{\circ} \mathrm{C}$} & \multirow{2}{*}{$20^{\circ} \mathrm{C} / 60 \%$} & Impermeable & 6.8 Aa & $3.6 \mathrm{Bb}$ & $2.8 \mathrm{Bc}$ \\
\hline & & Permeable & $6.8 \mathrm{Aa}$ & $5.8 \mathrm{Ab}$ & $4.5 \mathrm{Ac}$ \\
\hline & \multirow{2}{*}{$25^{\circ} \mathrm{C} / 50 \%$} & Impermeável & $6.8 \mathrm{Aa}$ & $6.3 \mathrm{Bb}$ & $5.7 \mathrm{Ac}$ \\
\hline & & Permeável & $6.8 \mathrm{Aa}$ & $7.0 \mathrm{Aa}$ & $5.5 \mathrm{Ab}$ \\
\hline & \multirow{2}{*}{$30{ }^{\circ} \mathrm{C} / 40 \%$} & Impermeable & $6.8 \mathrm{Aa}$ & $0.0 \mathrm{Ab}$ & 0.0 Ab \\
\hline & & Permeable & $6.8 \mathrm{Aa}$ & $0.0 \mathrm{Ab}$ & $0.0 \mathrm{Ab}$ \\
\hline \multirow{6}{*}{$75^{\circ} \mathrm{C}$} & \multirow{2}{*}{$20{ }^{\circ} \mathrm{C} / 60 \%$} & Impermeable & $7.4 \mathrm{Aa}$ & $3.5 \mathrm{Bb}$ & $3.0 \mathrm{Bc}$ \\
\hline & & Permeable & $7.4 \mathrm{Aa}$ & $7.0 \mathrm{Ab}$ & $6.2 \mathrm{Ac}$ \\
\hline & \multirow{2}{*}{$25^{\circ} \mathrm{C} / 50 \%$} & Impermeable & $7.4 \mathrm{Aa}$ & $6.6 \mathrm{Ab}$ & $6.0 \mathrm{Ac}$ \\
\hline & & Permeable & $7.4 \mathrm{Aa}$ & $4.9 \mathrm{Bb}$ & 4.3 Bc \\
\hline & \multirow{2}{*}{$30{ }^{\circ} \mathrm{C} / 40 \%$} & Impermeable & $7.4 \mathrm{Aa}$ & $0.0 \mathrm{Ab}$ & $0.0 \mathrm{Ab}$ \\
\hline & & Permeable & $7.4 \mathrm{Aa}$ & $0.0 \mathrm{Ab}$ & $0.0 \mathrm{Ab}$ \\
\hline
\end{tabular}

Means followed by the capital letter in the column for each package and lower lines for each storage time, do not differ at $5 \%$ probability. Coefficient of variation $(\mathrm{CV})=6.25 \%$. 
from three months of storage were influenced by the wrapping packaging used (Tables 12 and 13), whereas, in the latter storage time. The process of deterioration influences the performance of the same, so the increase in seed deterioration provides lower seedling growth and root, called out by the loss of vigor, culminating in the loss of germination (SILVA et al., 2010).

The loss of seed germination and early detection of physiological deterioration are important aspects to be considered in storage thus the percentage of seed moisture and storage temperatures are the primary factors that can be manipulated and controlled to minimize the deterioration of seeds preserved in long term (ALMEIDA et al., 2010).

\section{Conclusions}

The physiological potential of sunflower seeds was affected by drying temperatures and storage conditions. The drying air temperature above $45^{\circ} \mathrm{C}$ negatively affected the quality of sunflower seeds. Permeable and waterproof packaging not guaranteed the quality of sunflower seeds during storage. The quality of sunflower seeds stored up time of three months was negatively affected. The conditions of $20^{\circ} \mathrm{C}$ and $60 \% \mathrm{RH}$ air were more favorable for the preservation of physiological quality of sunflower seed during the storage time.

\section{Acknowledgement}

The authors thank FUNDECT - MS for financial support for the development of research.

\section{References}

ALMEIDA, F. A. C. et al. Estudo de técnicas para o armazenamento de cinco oleaginosas em condições ambientais e criogênicas. Revista Brasileira de Produtos Agroindustriais, Campina Grande, v. 12, n. 2, p. 189-202, 2010.

AZEVEDO, M. R. Q. A. et al. Influência das embalagens e condições de armazenamento no vigor de sementes de gergelim. Revista Brasileira de Engenharia Agrícola e Ambiental, Campina Grande, v. 7, n. 3, p. 519-524, 2003. http://dx.doi.org/10.1590/ S1415-43662003000300019.

BAILEY, J. E. Whole grain storage. In: SAUER, D. B. (Ed.). Storage of cereal grains and their products. Minnesota: American Association of Cereal Chemists, 1992. 615 p.

BENNETT, M. A. Seed vigor and seed performance. Dept. of Horticulture and Crop Science Ohio State University. Available from: $<$ http://seedbiology.osu.edu/HCS631_files/14A $\% 20$ seed $\% 20$ vigor\%20and\%20performance\%20script.pdf $>$. Access in: 22 Jan. 2011

BRASIL. Ministério da Agricultura, Pecuária e Abastecimento. Regras para análise de sementes. Brasília: SNDA/DNDV/CLAV, 2009. 365 p.

CARVALHO, N. M.; NAKAGAWA, J. Sementes: ciência, tecnologia e produção. 4th ed. Jaboticabal: Funep, 2000.

FESSEL, S. A. et al. Teste de condutividade elétrica em sementes de soja armazenadas sob diferentes temperaturas. Bragantia, Campinas, v. 69, n. 1, p. 207-214, 2010. http://dx.doi.org/10.1590/ S0006-87052010000100026.

GUIMARÃES, R. N. et al. Efeito do tratamento de sementes com inseticidas na emergência e altura de plântulas de feijão. In: CONGRESSO NACIONAL DE PESQUISA DE FEIJÃO, 8. 2005, Goiânia. Anais... Goiânia: Embrapa Arroz e Feijão, 2005. p. 94-99.

MAGUIRE, J. D. Speed of germination - aid in selection and evaluation for seedling emergence and vigor. Crop Science, Madison, v. 2, n. 2, p. 176-177, 1962. http://dx.doi.org/10.2135/cropsci1962.001 1183X000200020033x.

MARCOS FILHO, J. Fisiologia de sementes de plantas cultivadas. Piracicaba: Esalq, 2005. 495 p.

MARTINS, L.; LAGO, A. A.; ANDRADE, A. C. S. Armazenamento de sementes de ipê branco: teor de água e temperatura do ambiente. Bragantia, Campinas, v. 68, n. 3, p. 775-780, 2009. http://dx.doi. org/10.1590/S0006-87052009000300026.

NAKAGAWA, J. Testes de vigor baseados no desempenho das plântulas. In: KRZYZANOWSKI, F. C. (Ed.). Vigor de sementes: conceitos e testes. Londrina: ABRATES, 1999. p. 21-24.

PRADHAN, R. C. et al. Moisture dependent physical properties of jatropha fruit. Industrial Crops and Products, Amsterdam, v. 29, n. 2, p. 341-347, 2009.

SANTOS, J. F. et al. Optimising tetrazolium test procedures to evaluate the physiological potential of peanut seeds. Seed Science and Technology, Zurich, v. 40, n. 2, p. 215-228, 2012. http://dx.doi. org/10.15258/sst.2012.40.2.07.

SILVA, F. S. et al. Viabilidade do armazenamento de sementes em diferentes embalagens para pequenas propriedades rurais. Revista de Ciências Agro-Ambientais, Alta Floresta, v. 8, n. 1, p. 45-56, 2010.

TOLEDO, M. Z. et al. Qualidade fisiológica e armazenamento de sementes de feijão em função da aplicação tardia de nitrogênio em cobertura. Pesquisa Agropecuária Tropical, Goiânia, v. 39, n. 2, p.124-133, 2009.

TONIN, G. A.; PEREZ, S. C. J. G. A. Qualidade fisiológica de sementes de Ocotea porosa (Nees et Martius ex. Nees) após diferentes condições de armazenamento e semeadura. Revista Brasileira de Sementes, Pelotas, v. 28, n. 2, p. 26-33, 2006. 